\title{
Synthesis, Spectral Characterization, in Vitro and in Silico Studies of Benzodioxin Pyrazoline derivatives
}

\author{
Prabha B. ${ }^{1}$, Ezhilarasi M.R. * (D) \\ 1 Department of Chemistry, Karpagam Academy of Higher Education, India \\ * Correspondence: mrezhilarasi@gmail.com;
}

Scopus Author ID 14043431700

Received: 29.07.2020; Revised: 27.08.2020; Accepted: 29.08.2020; Published: 1.09.2020

\begin{abstract}
The present study deals with the in silico and in vitro studies of DBDP derivatives, which is formed from the Michal-addition reaction of DihydroBenzo[b]Dioxin Chalcone Derivatives(DBDD) with hydrazine hydrate and carboxyethane. The DBDD were synthesized via Claisen condensation between substituted aldehyde and 1,4-(benzodioxan-6-yl)-methyl ketone. The newly arrived compounds were characterized by IR and NMR spectra. The structurally confirmed synthesized compounds were screened against 1UAG microbial protein, 1OQA cancer protein using auto dock software, and ADME properties also found by using (in silico) Swissadme and Molinspiration online tools. All the newly arrived DBDP compounds have passed the acceptable values of ADME (druglikeness), medicinal property, and lead likeness in ADME prediction. Compound DBDP-9 scored better values in drug-likeness. It obeys the five basic rules (Lipinski, Ghose, Verber, Egan, and Muegge) of medicinal chemistry property, passed the PAINS, Brenk filters with 0 violation, and also have better lead likeness value. All the other compounds in this series also passed the above-mentioned properties with 1 or 2 violations only present in PAINS and Brenk filter. This theoretical results incitement to performed docking and in vitro studies of the DBDP derivatives. Docking studies results that the good I.S averse to 1 UAG bacterial protein than standard drugs and also give impact values in the docking against 1OQA breast cancer protein. Overall observation from the above studies, DBDP-9 has a maximum oral absorption value $91.36 \%$ with 0 violation alert in drug-likeness, medicinal property, and pharmacokinetics filter. DBDP-4 has a good I.S (-8.8), DBDP-2 has 4 numbers of HBI as standard, and all the DBDP 1-9 compounds have higher I.S than the standard and also have impact I.S against 1OQA breast cancer protein.
\end{abstract}

Keywords: Multicomponent; Dihydro Dibenzo-dioxan; ADME; In vitro; In silico.

(C) 2020 by the authors. This article is an open-access article distributed under the terms and conditions of the Creative Commons Attribution (CC BY) license (https://creativecommons.org/licenses/by/4.0/).

\section{Introduction}

In the $21^{\text {st }}$ century, the world handshake with electronic gadgets and enters in the digitalized pathway. The computers lead in all the aspects, and it is also done tremendous help in the research area of science and the medicinal field. Computational methods are one of the most essential ones to predict the pharmacokinetics and biological properties of the designed organic compounds [1]. The information's about the drug-likeness property, binding affinity towards protein, toxicity, and absorption, distribution, metabolism, excretion (ADME) of the organic molecules are carried by using online protocols.

Low availability and scarcity of natural compounds [2] limited their chemotherapeutic importance. Due to this, the synthesis process of the hetero compound has more important. One of the most interesting and important five-membered heterocyclic systems is pyrazole, which 
has two "N" atom in its adjacent position $[3,4]$, and it has played the most important role in pharmacology. It has special attention in the field of medicinal and agro-chemistry and the pyrazole moiety present at the marketed drugs which are used as an anti-inflammatory (Celebrex), insecticide (Fipronil ${ }^{\circledR}$ ), neuroprotective agent (Endaravone), COX-2 inhibitor (Celecoxib) [5,6], antipyrine (prostaglandin $\mathrm{G} / \mathrm{H}$ synthase 2 inhibitors), anticoagulant $\left(\right.$ resaxaban ${ }^{\circledR}$ ) [7], and it also possessed anti-cancer activity, anti-viral agent [8, 9], antimicrobial [10,11], analgesic [12,13], antidepressant [14], antitumor [15,16], anti-hyperglycemic [17]. Pyrazole moiety has N-N linkage, which helps to its pharmacological property [18], and this $\mathrm{N}-\mathrm{N}$ linkage present in natural compounds is less in amounts. The creation of the N-N bond is very difficult for living micro-organisms, so this pyrazole moiety less abundant in natural compounds [19]. The most important and common method for synthesis of pyrazoline derivatives is the addition reaction of hydrazine hydrate with $\alpha, \beta$ - unsaturated compound [20]. The antimicrobial activity of 1,4-benzodioxane moiety was first proven by Mallesha et al. in the year 2011[21] as well in the year 2014, Sang et al. proved that the benzodioxane moiety could target FabH and play an important role against bacteria [22,23]. Dioxino substituted coumarin derivatives have antihepatotoxic activity [24], methylamine substituted dioxino derivative function as antipsychotic agent [25] and propionic acid substituted benzodioxane moiety has anti-inflammation property $[26,27]$.

Among this investigation, at present, we designed, synthesized benzodioxin substituted dihydro pyrazole derivatives (DBDP), and its electronic structure was confirmed with the help spectral data's taken from Brucker NMR and Schimadzu IR instruments. Then the targets are screened in silico and in vitro studies by using suitable online software and methods.

\section{Materials and Methods}

\subsection{Spectral devices.}

The melting point of the compounds was measured with the help of the MELT-TEMP apparatus. The IR values were recorded in the SHIMADZU FT-IR spectrometer using $\mathrm{KBr}$ as a reference. The ${ }^{1} \mathrm{H}$ and ${ }^{13} \mathrm{C}$ spectral values for BDP were noted from the BRUKER instrument at $400 \mathrm{~Hz}$ and $100 \mathrm{~Hz}$ with the help of TMS ILR (Internal Reference) and $\mathrm{CDCl}_{3}$ as a solvent. The preparation of DBDD compounds is followed by our previous work [28].

\subsection{Synthesis of DBDP.}

$0.025 \mathrm{~mol}$ chalcone derivatives dissolved in the $40 \mathrm{ml}$ of carboxyethane present at the $250 \mathrm{ml} \mathrm{RB}$ flask, and then nearly $1 \mathrm{ml}$ of hydrazine hydrate was added, shaken well, and it refluxed for 12-16 hours in the HM (Heating Mantle). The reaction was monitored by TLC; when completion occurs, the mixture poured into crushed ice to get a solid. The product finally it was filtered, dried, and its purity was checked by using TLC. The synthesis procedure of the DBDP compounds is followed by our previous work[29].

\section{1-(4,5-dihydro-3-(2,3-dihydrobenzo[b][1,4]dioxin-5-yl)-5-(4-chlorophenylpyrazol-1- yl))propan-1-one (DBDP-1):}

Yield 89; Pale yellow; molecular formula $\mathrm{C}_{20} \mathrm{H}_{19} \mathrm{ClN}_{2} \mathrm{O}_{3}$; $\mathrm{IR}\left(\mathrm{KBr}, \mathrm{cm}^{-1}\right): 1650.77(\mathrm{C}=\mathrm{N})$, 1694.16 (C=O), $1591.95(\mathrm{C}=\mathrm{C}), 1134.09(\mathrm{C}-\mathrm{N}), 2982.37$ (Aromatic $\mathrm{CH}), 2884.02$ (Aliphatic $\mathrm{CH}), 688.46,717.39,779.10,830.20 ;{ }^{1} \mathrm{H} \mathrm{NMR}\left(\mathrm{CDCl}_{3}, 400 \mathrm{MHz}\right): 1.150-1.192$ (3H,t), $2.75-$ $2.809(2 \mathrm{H}, \mathrm{d}), 3.03 \mathrm{ppm}\left(\mathrm{dd}, \mathrm{J}_{4 \mathrm{a}, 4 \mathrm{e}}=4 \mathrm{~Hz} \& \mathrm{~J}_{4 \mathrm{a}, 5 \mathrm{a}}=17.6 \mathrm{~Hz}\right) ; 3.66 \mathrm{ppm}\left(\mathrm{dd}, \mathrm{J}_{4 \mathrm{e}, 4 \mathrm{a}}=12 \mathrm{~Hz} \&\right.$ $\left.\mathrm{J}_{4 \mathrm{e}, 5 \mathrm{a}}=17.4 \mathrm{~Hz}\right) ; 5.50 \mathrm{ppm}\left(\mathrm{dd}, \mathrm{J}_{5 \mathrm{a}, 4 \mathrm{a}}=4.2 \mathrm{~Hz} \& \mathrm{~J}_{5 \mathrm{a}, 4 \mathrm{e}}=11.4 \mathrm{~Hz}\right), 4.29-4.33$ (dddd, $\left.\mathrm{J}=3.6 \mathrm{~Hz}\right)$; 
6.881-7.756 (m, Ar-H); ${ }^{13} \mathrm{C} \mathrm{NMR}\left(\mathrm{CDCl}_{3}, 100 \mathrm{MHz}, \mathrm{ppm}\right): 172.16(\mathrm{C}=\mathrm{O}) ; 27.54\left(\mathrm{C}-2^{2}\right) ; 9.20$ (C-3'); 153.20 (C-3); 42.04 (C-4); 59.46 (C-5); 64.57,64.27 (C $\mathrm{C}, \mathrm{Cb}_{\mathrm{b}}$ of dioxin); 133.24 (C-Cl); 115.59-145.69 (Ar-C).

1-(4,5-dihydro-3-(2,3-dihydrobenzo[b][1,4]dioxin-5-yl)-5-(4-nitrophenylpyrazol-1yl))propan-1-one (DBDP-2):

Yield 80; dark yellow; molecular formula $\mathrm{C}_{20} \mathrm{H}_{19} \mathrm{~N}_{3} \mathrm{O}_{5}$; IR $\left(\mathrm{KBr}, \mathrm{cm}^{-1}\right)$ : $1652.17(\mathrm{C}=\mathrm{N})$, $1693.16(\mathrm{C}=\mathrm{O}), 1592.31(\mathrm{C}=\mathrm{C}), 1142.12(\mathrm{C}-\mathrm{N}), 2982.31$ (Aromatic $\mathrm{CH}), 2886.12$ (Aliphatic $\mathrm{CH}), 689.26,765.43,825.34 ;{ }^{1} \mathrm{H}$ NMR $\left(\mathrm{CDCl}_{3}, 400 \mathrm{MHz}\right): 1.149-1.183(3 \mathrm{H}, \mathrm{t}), 2.742-2.799$ $(2 \mathrm{H}, \mathrm{d}), 3.04 \mathrm{ppm}\left(\mathrm{dd}, \mathrm{J}_{4 \mathrm{a}, 4 \mathrm{e}}=3.4 \mathrm{~Hz} \& \mathrm{~J}_{4 \mathrm{a}, 5 \mathrm{a}}=18 \mathrm{~Hz}\right) ; 3.62 \mathrm{ppm}\left(\mathrm{dd}, \mathrm{J}_{4 \mathrm{e}, 4 \mathrm{a}}=11.6 \mathrm{~Hz} \& \mathrm{~J}_{4 \mathrm{e}, 5 \mathrm{a}}=\right.$ $17.4 \mathrm{~Hz}) ; 5.47 \mathrm{ppm}\left(\mathrm{dd}, \mathrm{J}_{5 \mathrm{a}, 4 \mathrm{a}}=3.6 \mathrm{~Hz} \& \mathrm{~J}_{5 \mathrm{a}, 4 \mathrm{e}}=11.6 \mathrm{~Hz}\right), 4.31-4.33$ (dddd, J=3.6 Hz); 6.811-

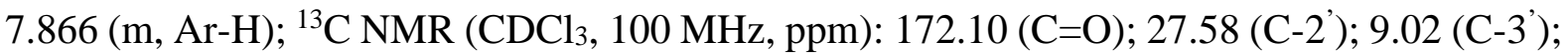
153.24 (C-3); 42.19 (C-4); 59.54 (C-5); 64.24,64.53 ( $\left.\mathrm{C}_{\mathrm{a}}, \mathrm{C}_{\mathrm{b}}\right)$; 114.23-148.16 (Ar-C).

1-(4,5-dihydro-3-(2,3-dihydrobenzo[b][1,4]dioxin-5-yl)-5-(4-methoxyphenylpyrazol-1yl))propan-1-one (DBDP-3):

Yield 85; yellowish white; molecular formula $\mathrm{C}_{21} \mathrm{H}_{22} \mathrm{~N}_{2} \mathrm{O}_{4}$; IR $\left(\mathrm{KBr}, \mathrm{cm}^{-1}\right)$ : $1654.21(\mathrm{C}=\mathrm{N})$, $1692.93(\mathrm{C}=\mathrm{O}), 1590.42(\mathrm{C}=\mathrm{C}), 1139.42(\mathrm{C}-\mathrm{N}), 2985.10$ (Aromatic $\mathrm{CH}), 2887.32$ (Aliphatic $\mathrm{CH}), 692.63,728.21,785.63,825.34 ;{ }^{1} \mathrm{H} \mathrm{NMR}\left(\mathrm{CDCl}_{3}, 400 \mathrm{MHz}\right): 1.150-1.187(3 \mathrm{H}, \mathrm{t}), 2.74-2.79$ $(2 \mathrm{H}, \mathrm{d}), 3.07 \mathrm{ppm}\left(\mathrm{dd}, \mathrm{J}_{4 \mathrm{a}, 4 \mathrm{e}}=3.8 \mathrm{~Hz} \& \mathrm{~J}_{4 \mathrm{a}, 5 \mathrm{a}}=17.4 \mathrm{~Hz}\right) ; 3.64 \mathrm{ppm}\left(\mathrm{dd}, \mathrm{J}_{4 \mathrm{e}, 4 \mathrm{a}}=11.8 \mathrm{~Hz} \& \mathrm{~J}_{4 \mathrm{e}, 5 \mathrm{a}}=\right.$ $17.4 \mathrm{~Hz}$ ); $5.49 \mathrm{ppm}\left(\mathrm{dd}, \mathrm{J}_{5 \mathrm{a}, 4 \mathrm{a}}=3.6 \mathrm{~Hz} \& \mathrm{~J}_{5 \mathrm{a}, 4 \mathrm{e}}=11.6 \mathrm{~Hz}\right), 4.29-4.31$ (dddd, J=3.4 Hz); 6.8197.599 (m, Ar-H); $3.76\left(\mathrm{OCH}_{3}\right):{ }^{13} \mathrm{C} \mathrm{NMR}\left(\mathrm{CDCl}_{3}, 100 \mathrm{MHz}, \mathrm{ppm}\right): 172.40(\mathrm{C}=\mathrm{O}) ; 27.51(\mathrm{C}-$ 2); 8.92 (C-3'); 153.05 (C-3); 41.88 (C-4); 59.53 (C-5); 64.29,64.59 (Ca $\left.\mathrm{C}_{\mathrm{b}}\right) ; 161.56$ (C$\left.\mathrm{OCH}_{3}\right) ; 115.64-149.16$ (Ar-C).

1-(4,5-dihydro-3-(2,3-dihydrobenzo[b][1,4] dioxin-5-yl)-5-(2,3-dichlorophenylpyrazol-1yl))propan-1-one (DBDP-4):

Yield 76; white; molecular formula $\mathrm{C}_{20} \mathrm{H}_{19} \mathrm{Cl}_{2} \mathrm{~N}_{2} \mathrm{O}_{3}$; IR $\left(\mathrm{KBr}, \mathrm{cm}^{-1}\right)$ : $1656.18(\mathrm{C}=\mathrm{N}), 1690.32$ $(\mathrm{C}=\mathrm{O}), 1593.54(\mathrm{C}=\mathrm{C}), 1139.12(\mathrm{C}-\mathrm{N}), 2981.92$ (Aromatic $\mathrm{CH}), 2888.63$ (Aliphatic $\mathrm{CH}$ ), 689.72,715.33,784.54,832.34; ${ }^{1} \mathrm{H}$ NMR (CDCl, $\left.400 \mathrm{MHz}\right): 1.148-1.188$ (3H,t), 2.746-2.781 $(2 \mathrm{H}, \mathrm{d}), 3.09 \mathrm{ppm}\left(\mathrm{dd}, \mathrm{J}_{4 \mathrm{a}, 4 \mathrm{e}}=3.8 \mathrm{~Hz} \& \mathrm{~J}_{4 \mathrm{a}, 5 \mathrm{a}}=17.6 \mathrm{~Hz}\right) ; 3.68 \mathrm{ppm}\left(\mathrm{dd}, \mathrm{J}_{4 \mathrm{e}, 4 \mathrm{a}}=11.6 \mathrm{~Hz} \& \mathrm{~J}_{4 \mathrm{e}, 5 \mathrm{a}}=\right.$ $17.6 \mathrm{~Hz}) ; 5.45 \mathrm{ppm}\left(\mathrm{dd}, \mathrm{J}_{5 \mathrm{a}, 4 \mathrm{a}}=3.4 \mathrm{~Hz} \& \mathrm{~J}_{5 \mathrm{a}, 4 \mathrm{e}}=11.4 \mathrm{~Hz}\right), 4.31-4.33$ (dddd, J=3.2 Hz); 6.799-

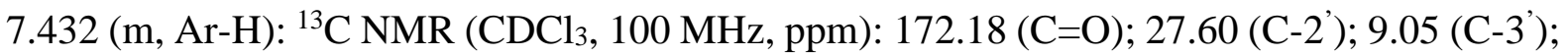
153.22 (C-3); 42.10 (C-4); 59.52 (C-5); 64.22,64.58 ( $\left.\mathrm{C}_{\mathrm{a}}, \mathrm{C}_{\mathrm{b}}\right) ; 130,132.22(\mathrm{C}-\mathrm{Cl}) ; 114.20-127.78$ (Ar-C); 143.43-147.79 (Ipso Carbon).

1-(4,5-dihydro-3-(2,3-dihydrobenzo[b][1,4]dioxin-5-yl)-5-(2-chlorophenylpyrazol-1yl))propan-1-one (DBDP-5):

Yield 80; Pale yellow; molecular formula $\mathrm{C}_{20} \mathrm{H}_{19} \mathrm{ClN}_{2} \mathrm{O}_{3}$; IR $\left(\mathrm{KBr}, \mathrm{cm}^{-1}\right)$ : $1651.18(\mathrm{C}=\mathrm{N})$, $1693.53(\mathrm{C}=\mathrm{O}), 1592.18(\mathrm{C}=\mathrm{C}), 1135.21(\mathrm{C}-\mathrm{N}), 2980.92$ (Aromatic $\mathrm{CH}), 2887.92$ (Aliphatic $\mathrm{CH}), 679.42,724.52,791.45,836.24 ;{ }^{1} \mathrm{H} \mathrm{NMR}\left(\mathrm{CDCl}_{3}, 400 \mathrm{MHz}\right): 1.152-1.175(3 \mathrm{H}, \mathrm{t}), 2.738-$ $2.789(2 \mathrm{H}, \mathrm{d}), 3.02 \mathrm{ppm}\left(\mathrm{dd}, \mathrm{J}_{4 \mathrm{a}, 4 \mathrm{e}}=3.6 \mathrm{~Hz} \& \mathrm{~J}_{4 \mathrm{a}, 5 \mathrm{a}}=17.8 \mathrm{~Hz}\right) ; 3.60 \mathrm{ppm}\left(\mathrm{dd}, \mathrm{J}_{4 \mathrm{e}, 4 \mathrm{a}}=11.4 \mathrm{~Hz} \&\right.$ $\left.\mathrm{J}_{4 \mathrm{e}, 5 \mathrm{a}}=17.4 \mathrm{~Hz}\right) ; 5.39 \mathrm{ppm}\left(\mathrm{dd}, \mathrm{J}_{5 \mathrm{a}, 4 \mathrm{a}}=3.8 \mathrm{~Hz} \& \mathrm{~J}_{5 \mathrm{a}, 4 \mathrm{e}}=11.8 \mathrm{~Hz}\right), 4.31-4.32$ (dddd, J= $\left.3.6 \mathrm{~Hz}\right)$; 6.810-7.652 (m, Ar-H): ${ }^{13} \mathrm{C} \mathrm{NMR}\left(\mathrm{CDCl}_{3}, 100 \mathrm{MHz}, \mathrm{ppm}\right): 172.21(\mathrm{C}=\mathrm{O}) ; 27.53\left(\mathrm{C}-2^{\prime}\right) ; 9.07$ (C-3'); 153.29 (C-3); 42.15 (C-4); 59.55 (C-5); 64.26,64.56 (C, $\left.\mathrm{C}_{\mathrm{b}}\right) ; 134.43$ (C-Cl); 115.21127.60 (Ar-C); 143.20-147.62 (Ipso Carbon).

1-(4,5-dihydro-3-(2,3-dihydrobenzo[b][1,4]dioxin-5-yl)-5-(4-bromophenylpyrazol-1yl))propan-1-one (DBDP-6):

Yield 76; brownish yellow; molecular formula $\mathrm{C}_{20} \mathrm{H}_{19} \mathrm{BrN}_{2} \mathrm{O}_{3}$; IR $\left(\mathrm{KBr}, \mathrm{cm}^{-1}\right): 1654.32(\mathrm{C}=\mathrm{N})$, 1694.25 (C=O), $1594.63(\mathrm{C}=\mathrm{C}), 1141.52(\mathrm{C}-\mathrm{N}), 2986.45$ (Aromatic $\mathrm{CH}), 2893.56$ (Aliphatic 
$\mathrm{CH}), 668.85,731.47,786.56,815.87 ;{ }^{1} \mathrm{H} \mathrm{NMR}\left(\mathrm{CDCl}_{3}, 400 \mathrm{MHz}\right): 1.151-1.177(3 \mathrm{H}, \mathrm{t}), 2.740-$ $2.785(2 \mathrm{H}, \mathrm{d}), 3.11 \mathrm{ppm}\left(\mathrm{dd}, \mathrm{J}_{4 \mathrm{a}, 4 \mathrm{e}}=3.6 \mathrm{~Hz} \& \mathrm{~J}_{4 \mathrm{a}, 5 \mathrm{a}}=17.6 \mathrm{~Hz}\right) ; 3.69 \mathrm{ppm}\left(\mathrm{dd}, \mathrm{J}_{4 \mathrm{e}, 4 \mathrm{a}}=11.6 \mathrm{~Hz} \&\right.$ $\left.\mathrm{J}_{4 \mathrm{e}, 5 \mathrm{a}}=17.8 \mathrm{~Hz}\right) ; 5.49 \mathrm{ppm}\left(\mathrm{dd}, \mathrm{J}_{5 \mathrm{a}, 4 \mathrm{a}}=3.4 \mathrm{~Hz} \& \mathrm{~J}_{5 \mathrm{a}, 4 \mathrm{e}}=11.4 \mathrm{~Hz}\right), 4.32-4.35$ (dddd, J= $\left.3.4 \mathrm{~Hz}\right)$; 6.795-7.821 (m, Ar-H): $\left.{ }^{13} \mathrm{C} \mathrm{NMR} \mathrm{(CDCl}, 100 \mathrm{MHz}, \mathrm{ppm}\right): 172.30(\mathrm{C}=\mathrm{O}) ; 27.55$ (C-2'); 9.04 (C-3'); 153.42 (C-3); 42.08 (C-4); 59.52 (C-5); 64.25,64.55 ( $\left.\mathrm{C}_{\mathrm{a}}, \mathrm{C}_{\mathrm{b}}\right)$; 115.30-149.62 (Ar-C).

1-(4,5-dihydro-3-(2,3-dihydrobenzo[b][1,4]dioxin-5-yl)-5-(4-methylphenylpyrazol-1yl))propan-1-one (DBDP-7):

Yield 85; light yellow; molecular formula $\mathrm{C}_{21} \mathrm{H}_{22} \mathrm{~N}_{2} \mathrm{O}_{3}$; IR $\left(\mathrm{KBr}, \mathrm{cm}^{-1}\right)$ : $1656.84(\mathrm{C}=\mathrm{N})$, $1695.78(\mathrm{C}=\mathrm{O}), 1593.18(\mathrm{C}=\mathrm{C}), 1145.48(\mathrm{C}-\mathrm{N}), 2984.67$ (Aromatic $\mathrm{CH}), 2886.34$ (Aliphatic $\mathrm{CH}), 672.45,724.78,768.87,826.54 ;{ }^{1} \mathrm{H} \mathrm{NMR}\left(\mathrm{CDCl}_{3}, 400 \mathrm{MHz}\right): 1.154-1.178(3 \mathrm{H}, \mathrm{t}), 2.739-$ $2.786(2 \mathrm{H}, \mathrm{d}), 3.06 \mathrm{ppm}\left(\mathrm{dd}, \mathrm{J}_{4 \mathrm{a}, 4 \mathrm{e}}=3.4 \mathrm{~Hz} \& \mathrm{~J}_{4 \mathrm{a}, 5 \mathrm{a}}=17.6 \mathrm{~Hz}\right) ; 3.59 \mathrm{ppm}\left(\mathrm{dd}, \mathrm{J}_{4 \mathrm{e}, 4 \mathrm{a}}=11.8 \mathrm{~Hz} \&\right.$ $\left.\mathrm{J}_{4 \mathrm{e}, 5 \mathrm{a}}=17.2 \mathrm{~Hz}\right) ; 5.49 \mathrm{ppm}\left(\mathrm{dd}, \mathrm{J}_{5 \mathrm{a}, 4 \mathrm{a}}=3.4 \mathrm{~Hz} \& \mathrm{~J}_{5 \mathrm{a}, 4 \mathrm{e}}=11.6 \mathrm{~Hz}\right), 4.34-4.36$ (dddd, J= $\left.3.6 \mathrm{~Hz}\right)$; 3.74,3.89 (3H of $\left.\mathrm{CH}_{3}\right) ; 6.802-7.874(\mathrm{~m}, \mathrm{Ar}-\mathrm{H}):{ }^{13} \mathrm{C} \mathrm{NMR}\left(\mathrm{CDCl}_{3}, 100 \mathrm{MHz}, \mathrm{ppm}\right): 172.34$ $\left.(\mathrm{C}=\mathrm{O}) ; 27.49\left(\mathrm{C}^{\prime}\right)^{\prime}\right)$; $9.06\left(\mathrm{C}^{\prime} 3^{\prime}\right) ; 153.10(\mathrm{C}-3) ; 41.98$ (C-4); $59.56(\mathrm{C}-5) ; 64.23,64.45\left(\mathrm{C}_{\mathrm{a}}, \mathrm{C}_{\mathrm{b}}\right)$; 114.59-148.25 (Ar-C).

1-(4,5-dihydro-3-(2,3-dihydrobenzo[b][1,4]dioxin-5-yl)-5-(4-fluorophenylpyrazol-1yl))propan-1-one (DBDP-8):

Yield 76; yellow; molecular formula $\mathrm{C}_{20} \mathrm{H}_{19} \mathrm{FN}_{2} \mathrm{O}_{3}$; IR $\left(\mathrm{KBr}, \mathrm{cm}^{-1}\right)$ : $1655.45(\mathrm{C}=\mathrm{N}), 1693.28$ $(\mathrm{C}=\mathrm{O}), 1591.36(\mathrm{C}=\mathrm{C}), 1144.25(\mathrm{C}-\mathrm{N}), 2985.34$ (Aromatic $\mathrm{CH}), 2884.75$ (Aliphatic $\mathrm{CH})$, 667.54,732.42,756.51,815.24; ${ }^{1} \mathrm{H}$ NMR $\left(\mathrm{CDCl}_{3}, 400 \mathrm{MHz}\right): 1.151-1.181(3 \mathrm{H}, \mathrm{t}), 2.731-2.779$ $(2 \mathrm{H}, \mathrm{d}), 3.04 \mathrm{ppm}\left(\mathrm{dd}, \mathrm{J}_{4 \mathrm{a}, 4 \mathrm{e}}=3.6 \mathrm{~Hz} \& \mathrm{~J}_{4 \mathrm{a}, 5 \mathrm{a}}=17.8 \mathrm{~Hz}\right) ; 3.64 \mathrm{ppm}\left(\mathrm{dd}, \mathrm{J}_{4 \mathrm{e}, 4 \mathrm{a}}=11.6 \mathrm{~Hz} \& \mathrm{~J}_{4 \mathrm{e}, 5 \mathrm{a}}=\right.$ 17.2 Hz); 5.49 ppm (dd, $\mathrm{J}_{5 \mathrm{a}, 4 \mathrm{a}}=3.4 \mathrm{~Hz} \& \mathrm{~J}_{5 \mathrm{a}, 4 \mathrm{e}}=11.8 \mathrm{~Hz}$ ), 4.30-4.32 (dddd, J=3.8 Hz); 6.791-

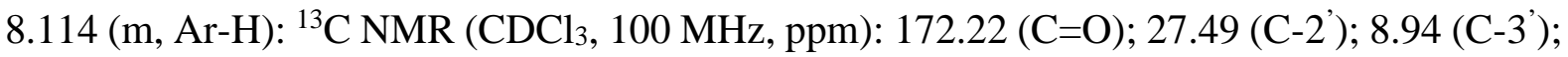
153.35 (C-3); 42.21 (C-4); 59.59 (C-5); 64.23,64.51 ( $\left.\mathrm{C}_{\mathrm{a}}, \mathrm{C}_{\mathrm{b}}\right)$; 114.46-148.56 (Ar-C).

\section{1-(4,5-dihydro-3-(2,3-dihydrobenzo[b][1,4]dioxin-5-yl)-5-phenylpyrazol-1-yl)propan-1- one (DBDP-9):}

Yield 72; pale yellow; molecular formula $\mathrm{C}_{20} \mathrm{H}_{19} \mathrm{~N}_{2} \mathrm{O}_{3}$; IR $\left(\mathrm{KBr}, \mathrm{cm}^{-1}\right)$ : $1650.63(\mathrm{C}=\mathrm{N})$, $1690.96(\mathrm{C}=\mathrm{O}), 1589.42(\mathrm{C}=\mathrm{C}), 1141.87(\mathrm{C}-\mathrm{N}), 2981.57$ (Aromatic $\mathrm{CH}), 2880.42$ (Aliphatic $\mathrm{CH}), 675.12,7542.86,808.75 ;{ }^{1} \mathrm{H}$ NMR $\left(\mathrm{CDCl}_{3}, 400 \mathrm{MHz}\right): 1.151-1.181(3 \mathrm{H}, \mathrm{t}), 2.731-2.779$ $(2 \mathrm{H}, \mathrm{d}), 3.02 \mathrm{ppm}\left(\mathrm{dd}, \mathrm{J}_{4 \mathrm{a}, 4 \mathrm{e}}=3.2 \mathrm{~Hz} \& \mathrm{~J}_{4 \mathrm{a}, 5 \mathrm{a}}=17.6 \mathrm{~Hz}\right) ; 3.64 \mathrm{ppm}\left(\mathrm{dd}, \mathrm{J}_{4 \mathrm{e}, 4 \mathrm{a}}=11.4 \mathrm{~Hz} \& \mathrm{~J}_{4 \mathrm{e}, 5 \mathrm{a}}=\right.$ $17.8 \mathrm{~Hz}) ; 5.45 \mathrm{ppm}\left(\mathrm{dd}, \mathrm{J}_{5 \mathrm{a}, 4 \mathrm{a}}=3.2 \mathrm{~Hz} \& \mathrm{~J}_{5 \mathrm{a}, 4 \mathrm{e}}=11.4 \mathrm{~Hz}\right), 4.35-4.38$ (dddd, J=3.8 Hz); 6.665-

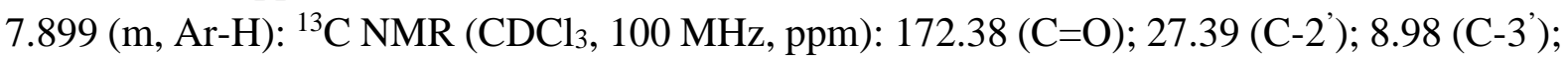
153.18 (C-3); 42.11 (C-4); 59.51 (C-5); 64.21,64.51 (C $\left.\mathrm{C}_{\mathrm{a}}, \mathrm{C}_{\mathrm{b}}\right)$; 114.12-147.88 (Ar-C).

\subsection{Antimicrobial screening test.}

The disk diffusion method is used to screen the antimicrobial studies of synthesized compounds DBDP, and MIC values are calculated by the microdilution method. The inoculums and sterile swabs are constructed and sterilized. Ciprofloxacin is used as a standard drug. The gram-positive $S$. aureus, St. pyogenes, and the gram-negative E. coli, P. aeruginosa bacterial strains and C.albicans fungal strain agar nutrient medium were prepared for the test. The reference procedures were adapted to do antimicrobial work[30]. 


\subsection{Computational method.}

\subsubsection{Molecular docking.}

The Auto dock 4.2.5.1 version program was used for molecular docking studies of synthesized DBDP derivatives. The given literary method followed to find the docking scores [31].

\subsubsection{ADME.}

Absorption, distribution, metabolism, and excretion (ADME) properties of all newly arrived DBDP were predicted using Swissadme online tool. That tool gave information about molecular weight (MW), $\log \mathrm{P}_{\mathrm{o} / \mathrm{w}}{ }^{\mathrm{c}}$ (octanol-water partition co-efficient, Log s(Solubility), $\log$ $\mathrm{k}_{\mathrm{p}}$ (skin permeation), hydrogen bond acceptor (HyA), number of hydrogen bond donor(HyD), polar surface area(TSPA), molar refractivity (M.Ref), bioavailability score. The given parameters help to understand the ADME property of any drugs or organic molecules. The molecule or the compounds which satisfy the Lipinski rule of five and some other below mentioned criteria are known as active drug molecule. The criteria for effective drug molecules are Molecular weight $\leq 500$, Hydrogen bond acceptor $\leq 10$, hydrogen bond donor $\leq 5, \log p \leq$ 5 , molar refractivity $\leq 140$ satisfy the rule of five and then $\log \mathrm{P}_{\mathrm{o} / \mathrm{w}}$ range between -2 to 6.5 , polar surface area range between 7 to $200, \log S$ range lie above -4 and the drug score value above 0.5 is accepted one for synthesized compounds. The pharmacokinetics, medicinal chemistry, and drug-likeness are also predicted from this tool.

The $\%$ Abs are calculated using the known formula [32, 33],

$$
\% \text { Abs }=109-0.345 * \text { TPSA }
$$

The molinspiration tool kit is used to predict the Bioactivity score of the synthesized compounds.Likewise GPCR ligand, Ion channel modulator, Kinase inhibitor, nuclear receptor ligand, Protease inhibitor, and Enzyme inhibitor values of DBDP compounds [32]. All DBDP compounds have a good drug-like score of 0.55 .

\section{Results and Discussion}

\subsection{Chemistry.}

The synthesis of DBDP molecules was achieved by adopting the Michal addition reaction of DBDD derivatives with hydrazine hydrate in the presence of sodium ethanoate as a multicomponent reaction (MCR). MCR reaction is the one of time-saving method which reduces the work time and solvent usage in the synthesis lab. It is also economical, product efficient. The starting DBDD (1-9) synthesized by Claisen-Schmidt condensation between various substituted benzaldehyde and 1,4-benzodioxan-6-yl-methyl ketone in the presence of a base medium. The pathway of the target is given in figure1.

\subsection{Computational analysis.}

\subsubsection{ADME prediction.}

A good drug is a compound in which one has an effective metabolism, absorbed at the required time, and well in distribution. The ADME study exhibits drug-likeness, medicinal property, pharmacokinetics property, and lead likeness of the compounds. The target molecules 
DBDP (1-9) ADME property predicted with the help of Swiss-ADME online software. This in silico method, plays a major role in helping to optimize the pharmacokinetic property of new molecules and increase the success rate. The target compounds DBDP (1-9) derivatives all obey the Lipinski's rule of five and also exhibit good solubility and absorption values. The ADME prediction values are given in table 1.

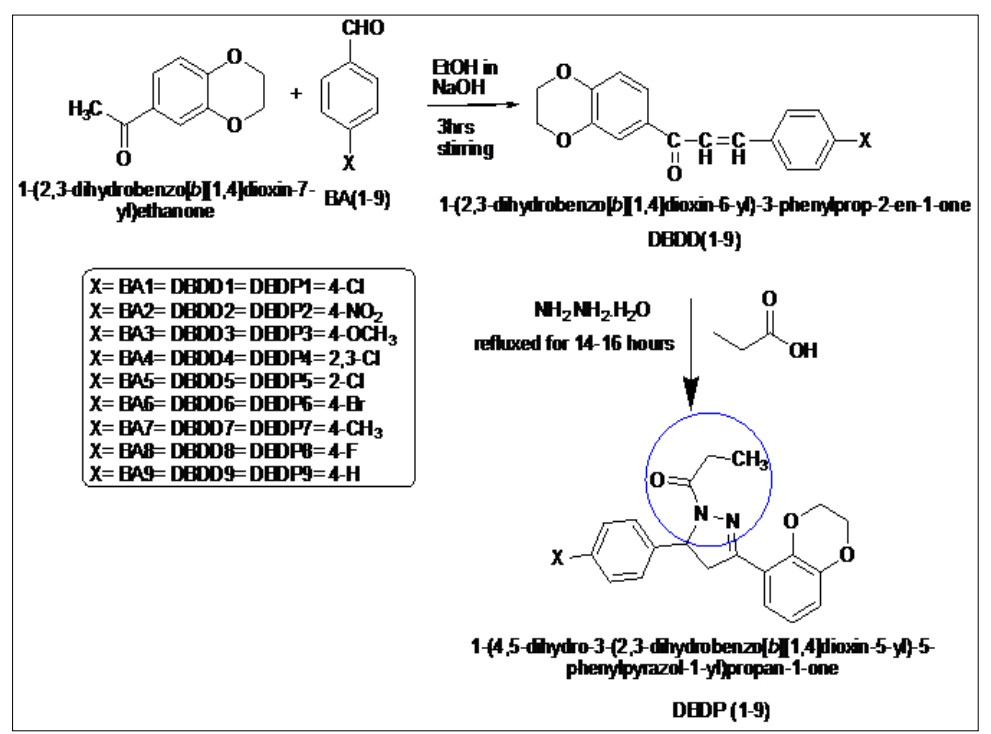

Figure 1. Representation of the schematic pathway of DBDP compounds.

\subsubsection{Oral absorption.}

DBDP compounds showed the best oral absorption values $91.63(\geq 80 \%)$, except DBDP-2 compound, which has a moderate absorption value of 74.22 (30 to $\leq 80 \%$ ). The halogenated substituted and electron-donating group substituted compounds DBDP-1,4,5,6,7,8 also have the best oral absorption value $91.63 \%$, and DBDP-3 has $88.17 \%$ oral absorption values.

\subsubsection{Drug-likeness.}

The compound DBDP-1, 5, 6, 8 are halogen-substituted ones. In that compounds DBDP-1 and DBDP-5 are chlorine substituted in the position 2 and 4, they two are having same ABME prediction values. While comparing the compounds DBDP-1,6,8, notable changes have occurred there. The Fluoro substituted DBDP-8 compound shows low solubility value, Log Pvalue, and M.Rty. values than the other two. Let us find the other two compounds DBDP-1,6 the DBDP-1 have less MW, low solubility, Log P, and M.Rty. values than DBDP-6. This shows that the molecular weight of the compounds heavily influencing the ADME values.

Compounds DBDP-2, $3 \& 7$ are the compounds having electron-withdrawing and electron-donating substituents. All have acceptable values in drug-likeness prediction. While DBDP-3 \& 7 have lower values in MW, solubility, Log P, n-HyA, n-HyD, and M.Rty than DBDP-2 compound. This ADME study results stimulated our research work towards docking and in vitro studies of the DBDP compounds.

The compounds DBDP (1-9) showed the 0 violations for Lipinski rule of five, solubility value in the range -3.62 to -4.92 , polar surface area 51.13 except DBDP-2 and 3 and permeability range is -5.83 to -7.04 . All these values are satisfied, good, and all targets are has a moderate drug score value is 0.55 . 


\subsection{Drug likeness and medicinal chemistry.}

The medicinal chemistry of the targeted compounds DBDP (1-9) is done by using the same Swissadme software. The Medicinal chemistry contains 5 basic rules, which are Lipinski, Ghose, Veber, Egan, and Muegge. These are the basic rules for finding the medicinal chemistry of the compounds which are synthesized one. The target compounds DBDP-1 to 9 are having 0 violations in all the rules. The PAINS and Brenk are the physicochemical filters to predict the compounds which are responsible for poor pharmacokinetics property. The PAINS is a filter that helps to identify the molecule, whether it is a response or not against the biological assays, and Brenk is a filter to identify compounds that have the accepted toxic level, chemical reactivity, and metabolically unstable. Lead-likeness is one of the parameters similar to druglikeness. There is 0 violation in the PAINS filter of all the DBDP compounds, and it exhibits a potent response of DBDP compounds against biological assays. Except for DBDP-2, all the compounds have 0 violations in Brenk filter exhibits that all the compounds are good pharmacokinetics property with including acceptable toxic level, chemically inactive, and proper metabolical stability. The Drug-likeness, lead likeness, pharmacokinetic property (PAINS, Brenk), and synthetic accessibility of the compounds are shown in table 2.

Particularly, the compound DBDP-9 attains 0 violations in lead likeness property. The compounds which are substituted by $\mathrm{CH}_{3}, \mathrm{OCH}_{3}, \mathrm{~F}, \mathrm{NO}_{2}$ have only one violation in $\mathrm{MW}>$ 350 , but it obeys all five basic rules and their molecular weight $<500$. The other four compounds that are 4-Cl, 2-Cl, 2,3-Cl, and 4- $\mathrm{Br}$ substitutions have two violations $\mathrm{MW}>350$, XLOGP3> 3.5 in the lead likeness parameter.

The identified values showed that all the DBDP compounds moderately active towards G-protein coupled receptor ligand. The entire compound also showed that moderately active towards Ion channel modulator, Kinase inhibitor, Nuclear receptor ligand, Protease inhibitor, and Enzyme inhibitor. The values are represented in Table-3.

\subsection{Docking studies.}

The target molecule DBDP (1-9) subjected molecular docking studies against bacterial protein 1 UAG and cancer cell line protein 1OQA. The docking resulted are given in Table-4 and Table-5, respectively. The cell wall mechanism involved in the in silico screening studies. The compound DBDP-4 has a high I.S. (Interaction Score) compared to other DBDP derivatives as well as standard drug ciprofloxacin. DBDP-4 scored -8.8 for I.S. and good Hbond interaction; it has two HBI (Hydrogen Bond Interaction) ARG A: 37 at $\mathrm{C}=\mathrm{O}$ group of propionyl group attached in the $1^{\text {st }}$ position of pyrazole ring, THR A: 36 obtained in the oxygen of dioxane moiety and three HPI (Hydrophobic Interaction) of ILE A: 74, PRO A: 72 \& LEU A: 15 present at the phenyl rings of the target compound. This compound has mark able binding score compared with standard and other compounds in the series.

DBDP-2 compound has the best I.S -7.2 with one HBI and one HPI. HBI formed GLN A: 104 substituted carbonyl group in the pyrazoline moiety and HPI PRO A: 59 formed at phenyl ring.

All the compounds in the series have a high I.S. score compare with standard drugs. In that, DBDP-3-9 compounds I.S. higher than -8.0 with one HBI at HIS A: 267 with bond length 2.06 and two HPI at LEU A: 263, ARG A: 302 with bond length 5.09, 5.12, the compound DBDP-5 has two H-bond interaction at ILE A:139, LEU A:141 and bond length is 2.82, 2.78 as like as the compound DBDP-4 but DBDP-5 have two hydrophobic interaction with VAL 
A:135, PRO A:300 amino acids at bond length 4.32,4.17. The DBDP-6,9 compounds have good I.S. -8.3,-8.4, but did not have any HBI and HPI.

The DBDP (1-9) compounds binding with the 1OQA protein, which belongs to the breast cancer cell line. The 9 target compounds have a good I.S. averse to 1OQA cell line with a notable number of HBI, and the maximum numbers of DBDP compounds form a HBI with GLN A: 104 at the $\mathrm{C}=\mathrm{O}$ of propionyl group, which is attached in the $1^{\text {st }}$ position of pyrazoline ring.

The electron-withdrawing substitution compound DBDP-1 and electron-donating substitution compound DBDP-3 are considerable I.S. with the maximum number of HBI at GLN A:104, GLY A: 72, GLN A: 73 and PHE A:68. This phenomenon shows that the substitution, even electron-donating or an electron-withdrawing enhances the binding affinity of the compounds averse to 1OQA protein. This interaction study also shows that all the 9 compounds may have a better ability to act as an anti-cancer drug. Docking studies established the mechanism for the interaction of protein and ligand binding. The docking results of some of the compounds showed in figure 2 , figure 3 , figure 4 , and figure 5.

\subsection{Antimicrobial study.}

The ADME and Molinspiration (in silico) study values incitement to carry out the in vitro studies of the compounds are treated antagonistically to gram-positive $S$. aureus, St. pyogenes gram-negative E. coli, $P$. aeruginosa, and fungal strain $C$. albicans. The study was done by $1 \mathrm{mg} / \mathrm{mL}$ concentration, and their results are exhibited in Fig 4. Ciprofloxacin used as a standard drug for bacterial strains $S$. aureus, E. coli, St. pyogenes, and P. aeruginosa, and Clotrimazole consider as a standard for fungal strain C. albicans.

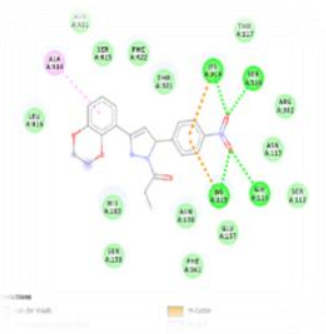

(a)

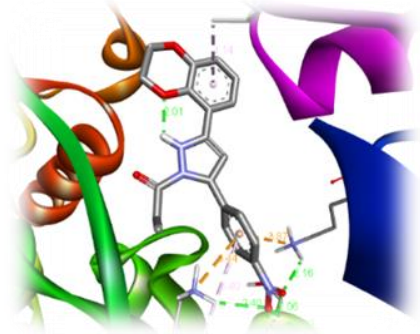

(b)

Figure 2. This is the figure belongs to the DBDP-2 compounds docking study averse to 1 UAG protein: (a) 2-D image of DBDP-2 against $1 \mathrm{UAG}$; (b) 3-D image of DBDP-2 against 1UAG.

Compounds DBDP-4, 5 showed better results while compared with standard, and they have a good zone of inhibition averse to bacterial strains. Especially, DBDP compounds show the best zone of inhibition against $E$. coli reveals the compound follow the cell wall synthesis mechanism. The compounds DBDP-1, 6, and 9 have good activity against $S$. pyogenes such as a standard. Compound DBDP-9 had a good inhibition against $E$. coli compared with standard and DBDP-6, 9 also had 90\% activity against $P$. aeruginosa compared with ciprofloxacin. DBDP-2,3 and 7 are substituted by electron-withdrawing, and electron-donating groups show a better activity against all the bacterial strains.

The results in figure 6 showed that the maximum DBDP compounds have a maximum inhibition activity averse to taken bacterial strains, and they had better activity against fungal strain. 


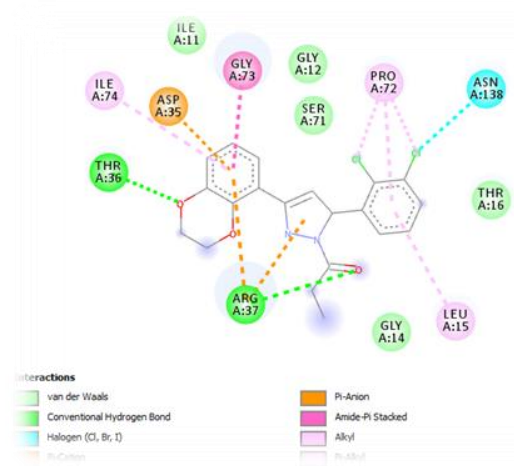

(a)

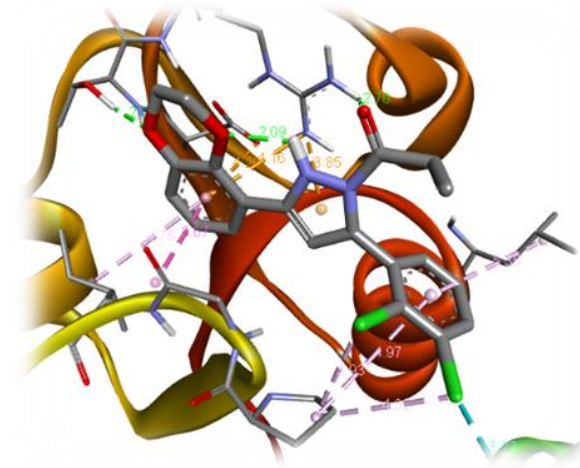

(b)

Figure 3. This is the figure belongs to the DBDP-5 compounds docking study averse to 1 UAG protein: (a) 2-D image of DBDP-5 against 1UAG ; (b) 3-D image of DBDP-5 against 1UAG.

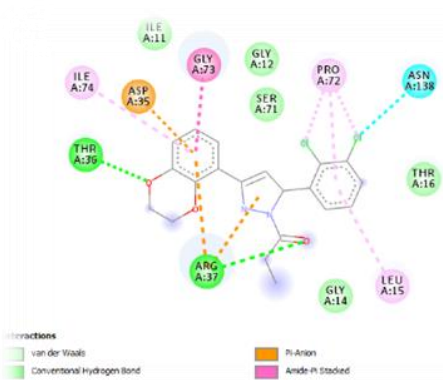

(a)

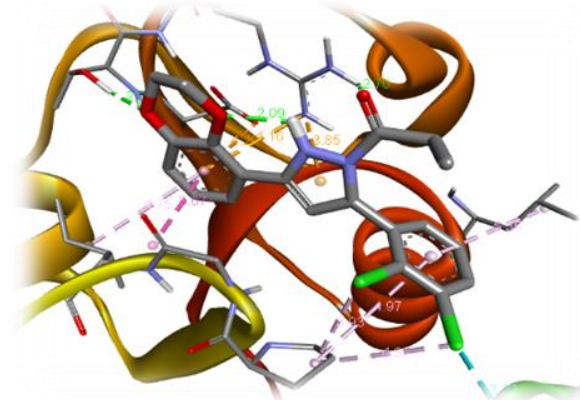

(b)

Figure 4. This is the figure belongs to the DBDP-4 compounds docking study averse to 1UAG protein: (a) 2-D image of DBDP-4 against 1UAG ; (b) 3-D image of DBDP-4 against 1UAG.

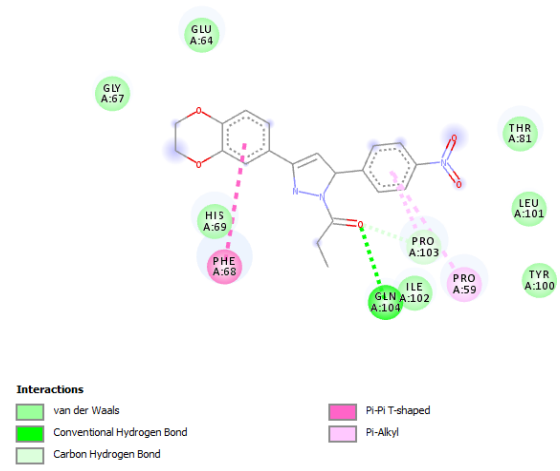

(a)

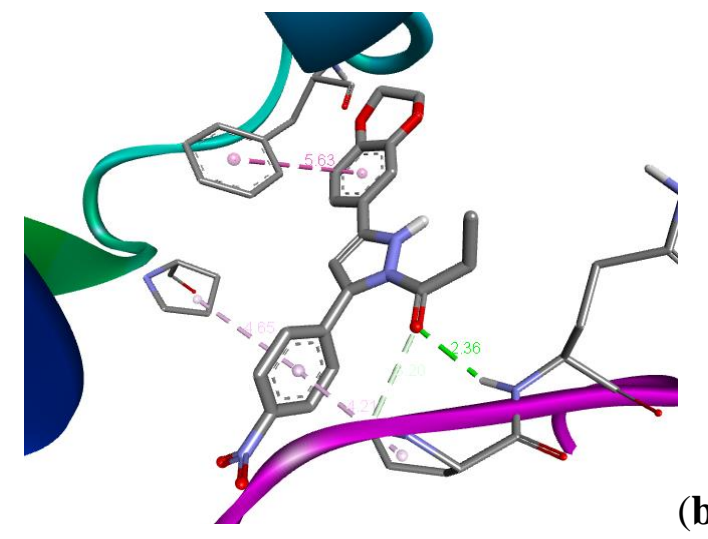

Figure 5. This is the figure belongs to the DBDP-2 compounds docking study averse to 1OQA protein: (a) 2-D image of DBDP-2 against 1OQA ; (b) 3-D image of DBDP-2 against 1OQA.

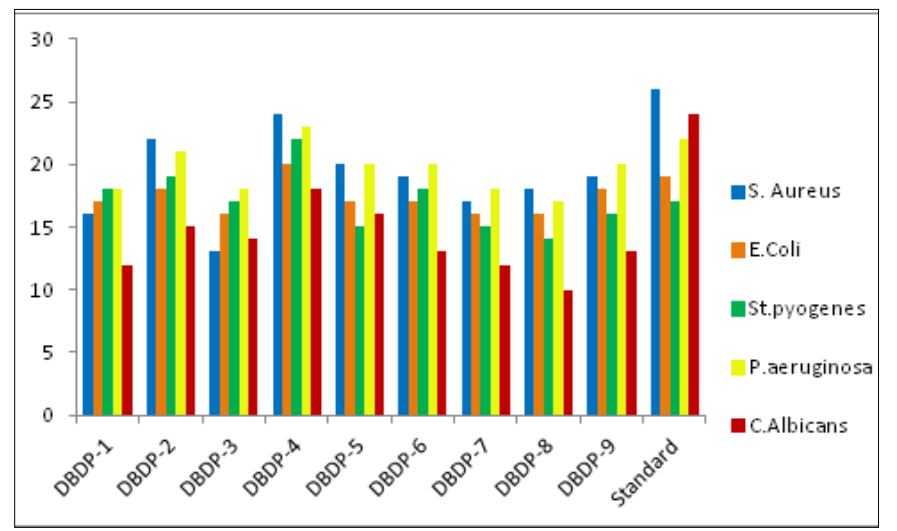

Figure 6. In vitro studies, results of compound DBDP (1-9) compounds at $1.0 \mathrm{mg} / \mathrm{mL}$ with a standard. 
Table 1. ADME prediction values of DBDP (1-9) compounds.

\begin{tabular}{|c|c|c|c|c|c|c|c|c|c|c|c|}
\hline Compound & $\begin{array}{c}\text { n-Heavy } \\
\text { atoms }\end{array}$ & MW & $\log P$ & n-HyA & n-HyD & M.Rty. & $\begin{array}{l}\text { n-violation of } \\
\text { rule of five }\end{array}$ & $\log S$ & $\begin{array}{c}\text { TSPA in } \\
\AA\end{array}$ & $\begin{array}{l}\text { Drug } \\
\text { Score }\end{array}$ & $\%$ Abs \\
\hline DBDP-1 & 26 & 370.83 & 3.59 & 4 & 0 & 107.71 & 0 & -4.28 & 51.13 & 0.55 & 91.36 \\
\hline DBDP-2 & 27 & 382.39 & 1.00 & 6 & 1 & 109.95 & 0 & -4.00 & 100.79 & 0.55 & 74.23 \\
\hline DBDP-3 & 26 & 366.41 & 3.06 & 5 & 0 & 109.20 & 0 & -3.79 & 60.36 & 0.55 & 88.18 \\
\hline DBDP-4 & 26 & 405.27 & 4.12 & 4 & 0 & 107.72 & 0 & -4.92 & 51.13 & 0.55 & 91.36 \\
\hline DBDP-5 & 27 & 370.83 & 3.59 & 4 & 0 & 107.71 & 0 & -4.28 & 51.13 & 0.55 & 91.36 \\
\hline DBDP-6 & 26 & 415.28 & 4.21 & 4 & 0 & 110.41 & 0 & -4.34 & 51.13 & 0.55 & 91.36 \\
\hline DBDP-7 & 28 & 350.41 & 3.39 & 4 & 0 & 107.67 & 0 & -4.00 & 51.13 & 0.55 & 91.36 \\
\hline DBDP-8 & 25 & 354.37 & 3.38 & 5 & 0 & 102.67 & 0 & -3.73 & 51.13 & 0.55 & 91.36 \\
\hline DBDP-9 & 26 & 336.38 & 3.07 & 4 & 0 & 102.71 & 0 & -3.62 & 51.13 & 0.55 & 91.36 \\
\hline
\end{tabular}

Acceptable values: n-Heavy atoms, MW<500, Log $\mathrm{P}<5$, n-HyA $\leq 10, \mathrm{n}-\mathrm{HyD} \leq 5$, M.Rty $<120, \log \mathrm{S} \leq-5$,

TPSA ( $30 \leq$ to $\geq 140$ ), Drug Score $\geq 0.5, \% A b s$ ( $\leq 80 \%$ (best), $30-80$ (moderate), $\geq 30 \%$ (poor)).

Table 2. Drug likeness and medicinal chemistry.

\begin{tabular}{l|l|l|l|l|l|l|l|l|l} 
Compound & Lipinski & Ghose & Veber & Egan & Muegge & PAINS & Brenk & Lead likeness & $\begin{array}{l}\text { Synthetic } \\
\text { accessibility }\end{array}$ \\
\hline DBDP-1 & $\begin{array}{l}\text { Y with 0 } \\
\text { violation }\end{array}$ & $\mathrm{Y}$ & $\mathrm{Y}$ & $\mathrm{Y}$ & $\mathrm{Y}$ & 0 & 0 & $\mathrm{~N}(2$ MW>350, XLOGP3>3.5 & 3.60 \\
\hline DBDP-2 & $\begin{array}{l}\text { Y with 0 } \\
\text { violation }\end{array}$ & $\mathrm{Y}$ & $\mathrm{Y}$ & $\mathrm{Y}$ & $\mathrm{Y}$ & 0 & $\begin{array}{l}1 \mathrm{NO}_{2} \\
\text { group })\end{array}$ & $\mathrm{N}$ (1 violation, MW> 350) & 3.75 \\
\hline DBDP-3 & $\begin{array}{l}\text { Y with 0 } \\
\text { violation }\end{array}$ & $\mathrm{Y}$ & $\mathrm{Y}$ & $\mathrm{Y}$ & $\mathrm{Y}$ & 0 & 0 & $\mathrm{~N}$ (1 violation, MW> 350) & 3.85 \\
\hline DBDP-4 & $\begin{array}{l}\text { Y with 0 } \\
\text { violation }\end{array}$ & $\mathrm{Y}$ & $\mathrm{Y}$ & $\mathrm{Y}$ & $\mathrm{Y}$ & 0 & 0 & $\mathrm{~N}(2$ MW>350, XLOGP3>3.5 & 3.78 \\
\hline DBDP-5 & $\begin{array}{l}\text { Y with 0 } \\
\text { violation }\end{array}$ & $\mathrm{Y}$ & $\mathrm{Y}$ & $\mathrm{Y}$ & $\mathrm{Y}$ & 0 & 0 & $\mathrm{~N}(2$ MW>350, XLOGP3>3.5 & 3.76 \\
\hline DBDP-6 & $\begin{array}{l}\text { Y with 0 } \\
\text { violation }\end{array}$ & $\mathrm{Y}$ & $\mathrm{Y}$ & $\mathrm{Y}$ & $\mathrm{Y}$ & 0 & 0 & $\mathrm{~N}(2$ MW>350, XLOGP3>3.5 & 3.73 \\
\hline DBDP-7 & $\begin{array}{l}\text { Y with 0 } \\
\text { violation }\end{array}$ & $\mathrm{Y}$ & $\mathrm{Y}$ & $\mathrm{Y}$ & $\mathrm{Y}$ & 0 & 0 & $\mathrm{~N}(1$ violation, MW> 350) & 3.80 \\
\hline DBDP-8 & $\begin{array}{l}\text { Y with 0 } \\
\text { violation }\end{array}$ & $\mathrm{Y}$ & $\mathrm{Y}$ & $\mathrm{Y}$ & $\mathrm{Y}$ & 0 & 0 & $\mathrm{~N}$ (1 violation, MW> 350) & 3.71 \\
\hline DBDP-9 & $\begin{array}{l}\text { Y with 0 } \\
\text { violation }\end{array}$ & $\mathrm{Y}$ & $\mathrm{Y}$ & $\mathrm{Y}$ & $\mathrm{Y}$ & 0 alert & 0 alert & $\mathrm{Y}$ & 3.70
\end{tabular}

Table 3. Bioactivity of DBDP compounds by Molinspiration online tool.

\begin{tabular}{l|c|c|c|c|c|c} 
Compound & GPCR ligand & $\begin{array}{c}\text { Ion channel } \\
\text { modulator }\end{array}$ & $\begin{array}{c}\text { Kinase } \\
\text { inhibitor }\end{array}$ & $\begin{array}{c}\text { Nuclear } \\
\text { receptor ligand }\end{array}$ & $\begin{array}{c}\text { Protease } \\
\text { inhibitor }\end{array}$ & $\begin{array}{c}\text { Enzyme } \\
\text { inhibitor }\end{array}$ \\
\hline DBDP-1 & -0.36 & -0.92 & -0.59 & -0.54 & -0.49 & -0.46 \\
\hline DBDP-2 & -0.48 & -0.90 & -0.66 & -0.58 & -0.56 & -0.50 \\
\hline DBDP-3 & -0.38 & -0.93 & -0.57 & -0.53 & -0.47 & -0.44 \\
\hline DBDP-4 & -0.35 & -0.91 & -0.65 & -0.60 & -0.49 & -0.52 \\
\hline DBDP-5 & -0.38 & -0.97 & -0.64 & -0.62 & -0.52 & -0.54 \\
\hline DBDP-6 & -0.46 & -0.99 & -0.62 & -0.63 & -0.56 & -0.50 \\
\hline DBDP-7 & -0.35 & -0.93 & -0.54 & -0.50 & -0.48 & -0.44 \\
\hline DBDP-8 & -0.40 & -0.98 & -0.61 & -0.55 & -0.51 & -0.48 \\
\hline DBDP-9 & -0.37 & -0.95 & -0.59 & -0.55 & -0.47 & -0.44 \\
\hline Ciprofloxacin & 0.12 & -0.04 & -0.07 & -0.19 & -2.0 & -0.28
\end{tabular}

Table 4. I.S., HBI and HPI of compounds DBDP (1-9) averse to 1 UAG protein.

\begin{tabular}{|c|c|c|c|c|c|}
\hline Compound & I.S & HBI-bond length & HBI & HPI- bond length & HPI \\
\hline DBDP-1 & -7.9 & 2.07 & HIS A: 267 & $\begin{array}{l}5.12, \\
6.08\end{array}$ & LEU A: 263,ARG A: 302 \\
\hline DBDP-2 & -7.9 & $\begin{array}{l}2.01,2.16 \\
2.40,2.63\end{array}$ & $\begin{array}{l}\text { LYS A: } 319, \text { SER A: } 116, \\
\text { LYS A: } 115, \text { GLY A: } 114\end{array}$ & 5.40 & ALA A: 414 \\
\hline DBDP-3 & -8.3 & 2.06 & HIS A: 267 & $\begin{array}{l}5.09, \\
5.12\end{array}$ & LEU A: 263,ARG A: 302 \\
\hline DBDP-4 & -8.8 & $2.09,2.70$ & THR A: 36,ARG A: 37 & $4.97,4.75,5.35$ & ILE A: 74,PRO A: 72, LEU A: 15 \\
\hline DBDP-5 & -8.0 & $2.82,2.78$ & ILE A: 139, LEU A: 141 & $4.32,4.17$ & VAL A: 135, PRO A: 300 \\
\hline DBDP-6 & -8.3 & - & - & - & - \\
\hline DBDP-7 & -8.6 & 2.27 & ASN A: 268 & - & - \\
\hline DBDP-8 & -8.6 & 2.31 & ASN A: 268 & - & - \\
\hline DBDP-9 & -8.4 & - & - & - & - \\
\hline Ciprofloxacin & -7.7 & $\begin{array}{l}2.05 \\
2.65 \\
2.47\end{array}$ & $\begin{array}{l}\text { ASN A: } 178, \\
\text { ASN A: } 271 \text {, } \\
\text { GLU A: } 327\end{array}$ & 4.12 & ALA A: 328 \\
\hline
\end{tabular}


Table 5. I.S., HBI and HPI of compounds DBDP (1-9) averse to 1OQA protein.

\begin{tabular}{|c|c|c|c|c|c|}
\hline Compound & I.S & HBI- bond length & HBI & HPI- bond length & HPI \\
\hline DBDP- 1 & -7.0 & $2.69,2.59,2.65,2.27$ & $\begin{array}{l}\text { GLN A: } 104, \text { GLY A: } 72 \text {, } \\
\text { GLN A: 73,PHE A: } 68\end{array}$ & 5.40 & ILE A: 105 \\
\hline DBDP- 2 & -7.2 & 2.36 & GLN A: 104 & 4.65 & PRO A: 59 \\
\hline DBDP- 3 & -6.6 & $2.34,2.52,2.64,2.68$ & $\begin{array}{l}\text { GLN A: } 104, \text { GLN A: } 73 \text {, } \\
\text { GLY A: 72,PHE A: } 68\end{array}$ & - & - \\
\hline DBDP- 4 & -6.9 & $2.52,2.32$ & $\begin{array}{l}\text { PHE A: } 68 \\
\text { HIS A: } 69\end{array}$ & $4.69,4.20,4.90$ & $\begin{array}{l}\text { PRO A: } 59, \text { PRO A: } 103 \text {, } \\
\text { ILE A: } 102\end{array}$ \\
\hline DBDP- 5 & -7.0 & $2.65,2.83$ & $\begin{array}{l}\text { GLN A: } 73, \\
\text { GLN A: } 104\end{array}$ & 5.35 & PRO A: 59 \\
\hline DBDP- 6 & -7.0 & 2.37 & GLN A: 104 & 4.65 & PRO A: 59 \\
\hline DBDP- 7 & -6.8 & $2.41,2.59$ & $\begin{array}{l}\text { HIS A: } 69 \\
\text { PHE A: } 68\end{array}$ & $5.16,4.94,4.82,4.74$ & $\begin{array}{l}\text { PRO A: 59, PRO A: } \\
\text { 103, ILE A: 102,VAL } \\
\text { A: } 57\end{array}$ \\
\hline DBDP- 8 & -6.6 & $2.31,2.55$ & $\begin{array}{l}\text { HIS A: } 69, \\
\text { PHE A: } 68\end{array}$ & $4.71,4.62,5.23$ & $\begin{array}{l}\text { PRO A: 59,PRO A: 103, } \\
\text { ILE A: } 102\end{array}$ \\
\hline DBDP- 9 & -6.8 & $2.63,2.89$ & $\begin{array}{l}\text { GLN A: } 73, \\
\text { GLN A: } 104\end{array}$ & $5.29,5.40$ & $\begin{array}{l}\text { PRO A: } 59 \\
\text { ILE A: } 102\end{array}$ \\
\hline
\end{tabular}

\section{Conclusions}

The newly designed DBDP derivatives were successfully synthesized, and their skeleton sketch was confirmed by using spectral data values. The derivatives subjected to in silico study known as docking and ADME prediction. The compound DBDP-4 has better active against bacterial strain also had high I.S., HBI, HPI values in the in silico study averse to 1 UAG with acceptable ADME prediction values, and it has a moderate bioactive score. DBDP2 has better I.S. with a high number of HBI, which leads to better binding between the protein and the ligand with a moderate ADME score. DBDP-9 has a good oral absorption value with 0 violations of all the ADME study. It moderates averse to 1 UAG bacterial protein but better I.S. averse to 1OQA breast cancer protein with notable HBI and HPI interactions.

\section{Funding}

This research received no external funding.

\section{Acknowledgments}

This research has no acknowledgment.

\section{Conflicts of Interest}

The authors declare no conflict of interest.

\section{References}

1. Thomas, R.; Mary, Y.S.; Resmi, K.S.; Narayana, B.; Sarojini, S.B.K.; Armaković, S.; Armaković, S.J.; Vijayakumar, G.; Alsenoy, C.V.; Mohan, B.J. Synthesis and spectroscopic study of two new pyrazole derivatives with detailed computational evaluation of their reactivity and pharmaceutical potential. Journal of Molecular Structure 2019, 1181, 599-612, https://doi.org/10.1016/j.molstruc.2019.01.014.

2. Stefanes, N.M.; Toigo, J.; Maioral, M.F.; Jacques, A.V.; Chiaradia-Delatorre, L.D.; Perondi, D.M.; Ribeiro, A.A.B.; Bigolin, Á.; Pirath, I.M.S.; Duarte, B.F.; Nunes, R.J.; Santos-Silva, M.C. Synthesis of novel pyrazoline derivatives and the evaluation of death mechanisms involved in their antileukemic activity. Bioorganic \& Medicinal Chemistry 2019, 27, 375-382, https://doi.org/10.1016/j.bmc.2018.12.012.

3. Balachandar, S.; Sethuram, M.; Muthuraja, P.; Shanmugavadivu, T.; Dhandapani, M. Ligand based pharmacophoric modelling and docking of bioactive pyrazolium 3-nitrophthalate (P3NP) on Bacillus subtilis, Aspergillus fumigatus and Aspergillus niger - Computational and Hirshfeld surface analysis. Journal of Photochemistry and Photobiology B: Biology 2016, 163, 352-365, https://doi.org/10.1016/j.jphotobiol.2016.08.045. 
4. Arshad, M.N.; Birinji, A.S.; Khalid, M.; Asiri, A.M.; Al-Amry, K.A.; Aqlan, F.M.S.; Braga, A.A.C. Synthesis, spectroscopic, single crystal diffraction and potential nonlinear optical properties of novel pyrazoline derivatives: Interplay of experimental and computational analyses. Spectrochimica Acta Part A: Molecular and Biomolecular Spectroscopy 2018, 202, 146-158, https://doi.org/10.1016/j.saa.2018.04.069.

5. Ahmed, W.; Yan, X.; Hu, D.; Adnan, M.; Tang, R.-Y.; Cui, Z.-N. Synthesis and fungicidal activity of novel pyrazole derivatives containing 5-Phenyl-2-Furan. Bioorganic \& Medicinal Chemistry 2019, 27, 1-8, https://doi.org/10.1016/j.bmc.2019.115048.

6. Junges, A.F.; Pittaluga, E.P.; Zanatta, N.; Martins, M.A.P.; Bonacorso, H.G. Novel 4,5-bis(trifluoromethyl)1H-pyrazoles through a concise sequential iodination-trifluoromethylation reaction. Tetrahedron Letters 2019, 60, 1385-1388, https://doi.org/10.1016/j.tetlet.2019.04.031.

7. Sanad, S.M.H.; Hanna, D.H.; Mekky, A.E.M. Regioselective synthesis of novel antibacterial pyrazolebenzofuran hybrids: 2D NMR spectroscopy studies and molecular docking. Journal of Molecular Structure 2019, 1188, 214-226, https://doi.org/10.1016/j.molstruc.2019.03.088.

8. Priyadarsini, P.; Ujwala, B.; Rao, C.V.; Rao, V.M. Synthesis and antimicrobial activity of some novel pyrazoles. Der Pharm Lett. 2012, 4, 1123-1128.

9. Chate, A.V.; Relawar, A.A.; Bondle,G.M.; Sarkate,A.P.; Tiwari,S.V; Lokwanid, D.K. A new efficient domino approach for the synthesis of cumarin-pyrazolines as antimicrobial agents targeting bacterial Dalanine-D-alanine ligase. New. J. Chem.2019, 43, 9002-9011, https://doi.org/10.1039/C9NJ00703B.

10. Manju, N.; Kalluraya, B.; Asma; Kumar, M.S. Synthesis, computational and biological study of pyrazole derivatives. Journal of Molecular Structure 2019, 1193, 386-397, https://doi.org/10.1016/j.molstruc.2019.05.049.

11. El Shehry, M.F.; Ewies, E.F.; Zayed, E.M. Synthesis of New Pyrazole Derivatives, Their Anti-Inflammatory and Analgesic Activities, and Molecular Docking Studies. Russian Journal of General Chemistry 2019, 89, 492-498, https://doi.org/10.1134/S1070363219030216.

12. Kuthyala, S.; Hanumanthappa, M.; Madan Kumar, S.; Sheik, S.; Gundibasappa Karikannar, N.; Prabhu, A. Crystal, Hirshfeld, ADMET, drug-like and anti-cancer study of some newly synthesized imidazopyridine containing pyrazoline derivatives. Journal of Molecular Structure 2019, 1197, 65-72, https://doi.org/10.1016/j.molstruc.2019.07.031.

13. Tripathi, A.C.; Upadhyay, S.; Paliwal, S; Saref, S.K. N1-benzene sulfonyl-2-pyrazoline hybrids in neurological disorders: synthesis, biological screening and computational studies. EXCLIJ.2018, 17, 126148, https://doi.org/10.17179/excli2017-871.

14. Chen, K.; Zhang, Y.-L.; Fan, J.; Ma, X.; Qin, Y.-J.; Zhu, H.-L. Novel nicotinoyl pyrazoline derivates bearing $\mathrm{N}$-methyl indole moiety as antitumor agents: Design, synthesis and evaluation. European Journal of Medicinal Chemistry 2018, 156, 722-737,https://doi.org/10.1016/j.ejmech.2018.07.044.

15. Tok, F.; İrem Abas, B.; Çevik, Ö.; Koçyiğit-Kaymakçığlu, B. Design, synthesis and biological evaluation of some new 2-Pyrazoline derivatives as potential anti-cancer agents. Bioorganic Chemistry 2020, 102, https://doi.org/10.1016/j.bioorg.2020.104063.

16. Shaaban, M.R.; Mayhoub, A.S.; Farag, A.M. Recent advances in the therapeutic applications of pyrazolines, Expert Opin. Ther. Pat. 2012, 22, 253-291, https://doi.org/10.1517/13543776.2012.667403.

17. Ikhtiarudin, I.; Frimayanti, N. Microwave-assisted synthesis and in vivo anti-diabetic activity of 5-(2bromophenyl)-3-(naphthalen-1-yl)-4, 5-dihydro-1H-pyrazole, Empowering Science and Mathematics for Global Competitiveness: Proceedings of the Science and Mathematics International Conference (SMIC 2018), November 2-4, 2018, Jakarta, Indonesia 2019, 35-40, http://doi.org/10.1201/9780429461903-6.

18. Lingappa, M. Synthesis, antimicrobial and antioxidant activities of 1-(1,4-benzodioxane-2carbonyl)piperazine derivatives. European Journal of Chemistry 2011, 2, 193-199, https://doi.org/10.5155/eurjchem.2.2.193-199.282.

19. Sun, J.; He, W.; Liu, H.-Y.; Qin, J.; Ye, C.-L. Design, synthesis and molecular docking of 1,4-benzodioxane thiazolidinedione piperazine derivatives as FabH inhibitors. Bioorganic Chemistry 2019, 88, https://doi.org/10.1016/j.bioorg.2019.102958.

20. Farooq, S.; Ngaini, Z. One-Pot and Two-Pot Synthesis of Chalcone Based Mono and Bis-Pyrazolines. Tetrahedron Letters 2020, 61, https://doi.org/10.1016/j.tetlet.2019.151416.

21. Song, X.; Yang, Y.; Zhao, J.; Chen, Y. Synthesis and Antibacterial Activity of Cinnamaldehyde Acylhydrazone with a 1,4-Benzodioxan Fragment as a Novel Class of Potent $\beta$-Ketoacyl-Acyl Carrier Protein Synthase III (FabH) Inhibitor. Chemical and Pharmaceutical Bulletin 2014, 62, 1110-1118, https://doi.org/10.1248/cpb.c14-00485.

22. Ahmed, B.; Khan, S.; Alam, D.T. Synthesis and antihepatotoxic activity of some heterocyclic compounds containing the 1,4-dioxane ring system. Die Pharmazie 2003, 58, 173-176.

23. Birch, A.M.; Bradley, P.A.; Gill, J.C.; Kerrigan, F.; Needham, P.L. N-Substituted (2,3-Dihydro-1,4benzodioxin-2-yl)methylamine Derivatives as D2 Antagonists/5-HT1A Partial Agonists with Potential as Atypical Antipsychotic Agents. Journal of Medicinal Chemistry 1999, 42, 3342-3355, https://doi.org/10.1021/jm9910122. 
24. Vázquez, M.T.; Rosell, G.; Pujol, M.D. Synthesis and anti-inflammatory activity of rac-2-(2,3-dihydro-1,4benzodioxin)propionic acid and its R and S enantiomers. European Journal of Medicinal Chemistry 1997, 32, 529-534, https://doi.org/10.1016/S0223-5234(97)84016-0.

25. Ahmed,B.; Habibullah,H.; Khan,S. Chemistry and Pharmacology of Benzodioxanes. Chem Inform. 2009, 4, $65-77$.

26. Khumar, A.B.; M.R, E.; b, P. Molecular Docking Study of Novel Synthesized Pyrazole Derivatives and their Antibacterial Activity. Asian Journal of Chemistry 2018, 30, 741-746, https://doi.org/10.14233/ajchem.2018.20913.

27. Chinnamanayakar, R.; M.R, E. Synthesis and Characterization of 2-Phenylpyrazoline Derivatives and Evaluation of their Activities against Antimicrobial and Breast Cancer Cell Line in vitro and in silico Studies. Asian Journal of Chemistry 2019, 31, 1311-1320,https://doi.org/10.14233/ajchem.2019.21915.

28. Chinnamanayakar, R.; M.R, E.; b, P.; Kulandhaivel. In vitro Antimicrobial Activity and in silico activity of 1-Thiocarbamoyl Substituted Pyrazole Derivatives. Asian Journal of Chemistry 2018, 30, 783-789, https://doi.org/10.14233/ajchem.2018.20992.

29. Mathew, M.; Chinnamanayakar, R.; Ramanathan, E. Synthesis, Characterization, in vitro Antimicrobial Evaluation and in silico Molecular Docking and ADME Prediction of 4-Chlorophenyl Furfuran Derivatives bearing Pyrazole Moieties. Asian Journal of Chemistry 2020, 32, 1482-1490, https://doi.org/10.14233/ajchem.2020.22634.

30. Karrouchi, K.; Radi, S.; Ramli, Y.; Taoufik, J.; Mabkhot, Y.N.; Al-aizari, F.A.; Ansar, M.h. Synthesis and Pharmacological Activities of Pyrazole Derivatives: A Review. Molecules 2018, 23, 1-86, https://doi.org/10.3390/molecules23010134.

31. Zhao, Y.H.; Abraham, M.H.; Le, J.; Hersey, A.; Luscombe, C.N.; Beck, G.; Sherborne, B.; Cooper, I. RateLimited Steps of Human Oral Absorption and QSAR Studies. Pharmaceutical Research 2002, 19, 14461457, https://doi.org/10.1023/A:1020444330011.

32. Shaikh, M.H.; Subhedar, D.D.; Nawale, L.; Sarkar, D.; Kalam Khan, F.A.; Sangshetti, J.N.; Shingate, B.B. 1,2,3-Triazole derivatives as antitubercular agents: synthesis, biological evaluation and molecular docking study. MedChemComm 2015, 6, 1104-1116, https://doi.org/10.1039/C5MD00057B.

33. Zhang, X.; Qi, F.; Wang, S.; Song, J.; Huang, J. Synthesis, structure, in silico ADME evaluation and in vitro antioxidant of (E)-N-(4-ethylphenyl)-2-(isomeric methylbenzylidene)thiosemicarbazone derivatives. Journal of Molecular Structure 2020, 1199, https://doi.org/10.1016/j.molstruc.2019.126972.

34. Singh, S.; Gupta, A.K.; Verma, A. Molecular properties and bioactivity score of the aloe vera antioxidant compounds - in order to lead finding. Research Journal of Pharmaceutical, Biological and Chemical Sciences 2013, 4, 876-881. 